\title{
Reproductive performance of Nellore heifers raised in extensive system undergoing different vaccination protocols in fixed-time artificial insemination (FTAI)
}

\section{Ernest Schillings Neto ${ }^{1}$ Eriklis Nogueira ${ }^{2}$ iD Rodrigo Jardim ${ }^{3}$ Urbano Gomes Pinto de Abreu ${ }^{2}$ (D) Fabiana Andrade de Melo Sterza ${ }^{4}$ Aiesca Oliveira Pellegrin ${ }^{2}$ (iD) Raquel Soares Juliano ${ }^{2 *}$ (D)}

${ }^{1}$ Pós-graduação em Ciências Veterinárias, Universidade Federal de Mato Grosso do Sul (UFMS), Campo Grande, MS, Brasil. ${ }^{2}$ Empresa Brasileira de Pesquisa Agropecuária, Embrapa Pantanal, 79320900, Corumbá, MS, Brasil. E-mail: raquel.juliano@embrapa.br. ${ }^{*}$ Corresponding author.

${ }^{3}$ Fazenda Bodoquena, Miranda, MS, Brasil.

${ }^{4}$ Universidade Estadual de Mato Grosso do Sul (UEMS), Aquidauana, MS, Brasil.

ABSTRACT: This study evaluated the reproductive performance of Nellore heifers without previous vaccination undergoing fixed-time artificial insemination (FTAI) and subsequent natural breeding under different vaccination protocols against infectious bovine herpesvirus 1 (BHV-1), bovine viral diarrhea virus (BVDV), and bovine leptospirosis (BL). A total of 763 animals were included; the group assignment was as follows: T1, control without vaccination; T2, vaccination against BL; T3, vaccination against BHV-1and BVDV; T4,vaccination against combination of BL +BHV-1and BVDV. Vaccination was started 30 days before FTAI (D-40), and a booster dose was administered at D-10. Serological tests were used to verify the occurrence rate of natural infection by $B L, B H V-1$, and BVDV. Initial pregnancy was diagnosed at D30, D60, and D120 after FTAI. Final pregnancy rates were evaluated by group, weight, body-condition score, occurrence of estrus, inseminator, bull, and occurrence of abortions or embryonic death. In all groups, results indicated seropositivity of 100\% for leptospirosis, $77.0-94.0 \%$ for $B H V-1$, and 64.0-87.0\% for BVDV. The vaccination protocol was not a significant influencing factor of pregnancy rate and embryonic or fetal mortality; whereas, animal weight at the beginning of the breeding season and presence of estrus at FTAI were significant influencing factors of pregnancy rate. The vaccination protocol had no interference with the reproductive performance of the experimental groups.

Key words: beef cattle, immunization, leptospirosis, pregnancy rate, viral diseases.

Desempenho reprodutivo de novilhas Nelore criadas em sistema extensivo no Pantanal, submetidas a diferentes protocolos vacinais na Inseminação Artificial em tempo Fixo (IATF)

RESUMO: $O$ estudo foi conduzido para avaliar o desempenho reprodutivo de novilhas Nelore, não imunizadas para herpesvirus bovino tipo 1 (BHV-1), vírus da diarreia viral bovina (BVDV) e leptospirose bovina (LB), submetidas a diferentes protocolos vacinais em manejo de inseminação artificial em tempo fixo (IATF) e repasse com touro em monta natural. Um total de 763 animais foram distribuidos em quatro grupos: T1 - controle sem vacinação; T2 - vacinação contra LB; T3 - vacinação contra BHV-1 e BVDV T4 - vacinação com LB+ BHV-1 e BVDV. A vacinação foi iniciada 30 dias antes da IATF (D-40) com a aplicação da segunda dose em D-10. Verificou-se a taxa de ocorrência de infecção natural por LB, BHV-1 e BVDV realizando-se exames sorológicos. O diagnóstico de gestação inicial foi feito aos 30 , 60 e 120 dias. Avaliou-se as taxas de prenhez em função dos grupos, do peso, escore de condição corporal, presença ou ausência de cio, inseminador, touro, ocorrência de abortos ou morte embrionária. Os resultados obtidos revelaram que soropositividade para leptospirose foi de $100 \%$ para todos os grupos, variando de 77,0\% a 94,0\% para BHV-1 e 64,0\% a 87,0\% para BVDV. O protocolo vacinal não interferiu na taxa de prenhez, de mortalidade embrionária ou fetal. Houve diferença na taxa de prenhez em relação ao peso dos animais no início da estação reprodutiva e a presença de cio no momento da IATF. Concluiu-se que o protocolo vacinal não interferiu no desempenho reprodutivo dos grupos experimentais.

Palavras-chave: doenças virais, gado de corte, imunização, leptospirose, taxa de prenhez.

\section{INTRODUCTION}

Beef is an important product in the Brazilian trade balance. Brazilian Agribusiness Foreign Trade Statistics System (AGROSTAT BRAZIL) reports indicated that beef was the only type of meat with positive performance in the sector, showing an increase in exports of $17.6 \%$ in the period from July, 2016 to June, 2018. The Central-West region of Brazil represents $33.8 \%$ of the national production.

In this region, beef cattle production systems are mostly extensive, and suited to the climate, 
landform and soil. In addition, large processing plants have enabled large-scale slaughtering. Mato Grosso do Sul has the fourth largest cattle herd in the country, with an increase of $2.81 \%$ in 2017 compared to that in 2016 (IBGE, 2015), which highlights the importance of this state in the meat production chain.

Pantanal mostly has a traditional livestock breeding system, which provides animals weaned or older than 1 year (12 to 18 months) for rearing, and fattening and finishing production systems located in the surrounding and plateau areas. In this region, breeding cows presented low performance rates, with a birth rate of around 58\% under traditional system (ABREU et al., 2000; SANTOS et al., 2002).

However, the introduction of fixedtime artificial insemination (FTAI) in reproductive management associated with technologies such as estrus detection marking, use of cooled semen, early weaning, nutritional supplementation for cows, and additional use of cultivated pastures, has contributed to increased pregnancy rates in the Pantanal area (ABREU et al., 2018; BORGES et al., 2018; NOGUEIRA et al., 2016; NOGUEIRA et al., 2011).

FTAI is also helpful to evaluate and monitor the reproductive-performance indices and verify the efficiency of hormonal and health protocols that are used to ensure a profit margin above implementation costs of the technology in the production system. In this context, maternity fund as a phenomenon of gestational loss was observed.

This indicator is used to evaluate the reproductive efficiency considering the number of cows identified as pregnant that did not calve at the end of the breeding season. Technicians and researchers consider a normal or acceptable rate of 5 to $6 \%$,and this rate may increase due to wide distribution of reproductive diseases such as infectious bovine rhinotracheitis (IBR), bovine viral diarrhea (BVD), and leptospirosis in Brazilian herds (GRANDO, 2016; ALFIERI \& ALFIERI, 2017).

Some epidemiological studies have reported the presence of these infectious agents in herds in the Pantanal area in Mato Grosso do Sul (PELLEGRIN et al., 1997; PELLEGRIN et al., 1999; JULIANO et al., 2011; AONO et al., 2013, which when combined with gestational loss, has justified implementation of health management programs in livestock production systems following the recommended annual vaccination protocol against reproductive diseases for cows (dose and booster), preferably before starting reproductive management. However, the impact of these agents and/ or a prophylactic protocol on reproductive performance in cows is not fully known.
Reproductive efficiency is a priority in livestock breeding systems and any procedure economically feasible and efficient to improve herd performance is essential to guarantee greater productivity and sustainability of the system as a whole. Considering the hypothesis of association between gestational loss and infectious diseases, this study aimed to evaluate reproductive indices of heifers raised in extensive system undergoing different vaccination protocols against BHV-1, $\mathrm{BVDV}$, and bovine leptospirosis (BL).

\section{MATERIALS AND METHODS}

Study site. A farm of 78,000-ha total area with $50 \%$ of the site located in the Pantanal area that had a history of gestational loss and seropositivity for BHV-1, BVDV, and BL was targeted.

Climate in the area is defined as Köppen's AW (tropical wet-dry), with well-defined seasons, rainy in summer and dry in winter, and annual rainfall ranging from 800 to $1,200 \mathrm{~mm}$ (ALVARES et al., 2013).

Herd characterization: In the total herd, approximately 15,000 cows were under reproductive management of 3-month FTAI with breeding through natural service by bulls. Prophylactic management against BHV-1, BVDV, and BL including annual vaccination (dose and booster) for cows before the FTAI procedures was implemented.

Experimental animals: A total of 763 Nellore heifers raised in extensive system with cultivated and native pastures and undergoing mineral supplementation were included. The inclusion criteria were maturity of the reproductive tract (GUTIERREZ et al., 2014), weight above $250 \mathrm{~kg}$, body condition score (BCS) of $\geq 3$ (MAAS, 1987), and seronegative test for bovine brucellosis.

Health examinations: Serological evidences of infectious agents before implementation of the vaccine protocols were obtained with sample size of 8 to $10 \%$ of each of the groups. This samples were used to serological diagnosis by ELISA test (Idexx Laboratories Inc., Maine, USA) to detect BHV1 and BVDV, following the protocol recommended by the manufacturer, and microscopic serum agglutination test (MAT) to detect BL antibodies at $1: 100$ to $1: 1600$ dilution, according to the protocol described by SANTA ROSA (1970).

Live strains of leptospires from the following serovars maintained in EllinghausenMcCullough-Johnson-Harris (EMJH) medium were used as antigens: Australis, Autumnalis, Bratislava, 
Castellonis, Bataviae, Canicola, Whitcom, Cynopteri, Grippotyphosa, Copenhageni, Hebdomadis, Icterohaemorragiae, Javanica, Panama, Pomona, Hardjo, Wolffi, and Tarassovi.

Sample's positivity was considered if agglutination of $\geq 50 \%$ leptospires at minimum dilution of 1:100 for at least one of the serovars tested, was observed. With regard to prevalence, the serovar with the highest titer was considered for each animal. The highest agglutination titer for several serovars in a single individual was considered as co-agglutination. Only reactive animals were used to verify the frequency of serovar agglutination, regardless of title or co-agglutination (SANTA ROSA, 1970).

Treatments: The animals were homogeneously assigned into four groups: T1, control without vaccination $(\mathrm{n}=190)$; $\mathrm{T} 2$, vaccination against BL with two doses at 30-day interval $(n=195)$; $\mathrm{T} 3$, vaccination against $\mathrm{BHV}-1$ and $\mathrm{BVDV}$ with two doses at 30-day interval $(n=194)$; T4, vaccination against a combination of $\mathrm{BL}+\mathrm{BHV}-1$ and $\mathrm{BVDV}$ with two doses at 30-day interval $(n=184)$.

Vaccination treatments were administered as follows: first dose 30 days before starting FTAI (D-
40), and booster dose on the first day of FTAI (D-10). Vaccines contained live attenuated strains of BHV1, killed strains of BVDV (type 1 and 2), and live attenuated strains of leptospires.

FTAI protocol: In all heifers, the same reproductive management (Figure 1) using FixedTime Artificial Insemination (FTAI) protocol described by NOGUEIRA et al. (2011) was performed. On random day of the estrous cycle (D10), all females received 2-mg estradiol benzoate (RIC-BE ${ }^{\circledR}$, AgenerUnião, Brazil) and an intravaginal device with 1-g progesterone-p4 (Primer ${ }^{\circledR}$, AgenerUnião, Brazil). At D-2, the intravaginal device was removed, and 1-mg estradiol cypionate $\left(\mathrm{ECP}^{\circledR}\right.$, Zoetis, Brazil) was administered; in addition, 150- $\mu \mathrm{g}$ d-cloprostenol (Prolise ${ }^{\circledR}$, Arsa, Argentina) and 300IU equine chorionic gonadotrophin (ECG) (Folligon ${ }^{\circledR}$ 5000UI, MSD, São Paulo, Brazil) were administered. At implant removal, all cows were painted in the sacrocaudal region with marking crayons (RaidlMaxi, RAIDEX GmbH, Dettingen/Erms, Germany). At D0, about 54 hours after implant removal, all heifers received semen from the same bulls with known fertility. From D10 until D90 after FTAI, the

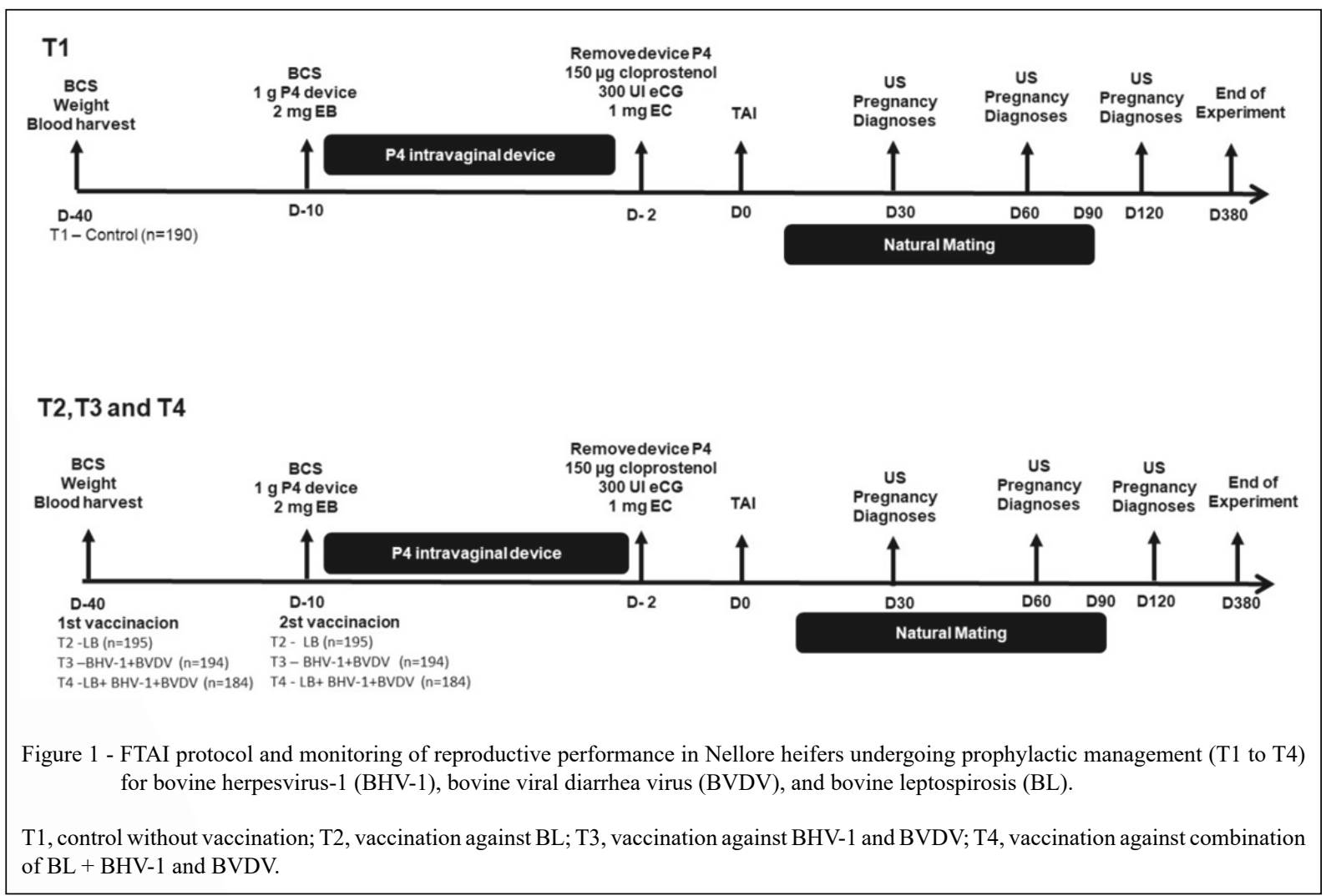

Ciência Rural, v.49, n.11, 2019. 
cows underwent natural breeding with service by bulls at a ratio of 1:30 (bull/cows).

Frozen semen and bulls were evaluated following the 2013 recommendations of the Brazilian College of Animal Reproduction (CBRA).A spreadsheet was used to record the presence of estrus that was detected by the marking method. (NOGUEIRA et al., 2016). The name of the FTAI inseminator (I), name of the bull used in FTAI (B), and name of the bull used in natural breeding for each group of heifers were recorded variables, equally distributed among the experimental groups.

Reproductive performance: Pregnancy was diagnosed by US at D30 after FTAI, and monitored by US at D60 to detect ED and at D120 to evaluate natural-breeding performance. FL was considered in the period between D60 and calving (Figure 1).

Body score: Body condition score (BCS) was evaluated using a scale from 1 to 5 at the beginning of FTAI and at the end of the procedures, before natural service. In all animals, the body weight (BW) was obtained at the beginning of the experiment.

Data analysis: Statistical analysis was performed using a generalized linear model with SAS GLIMMIX and PROC REG procedure (SAS Institute, Inc., Cary, NC, USA). In the model to evaluate pregnancy rate, treatment was included as variable, with FTAI as main effect, and subsequently the covariables of bull, BCS, estrus evaluated with the use of marker crayons, inseminator, initial weight, maturity of the reproductive tract, and interactions were added. In the models for embryonic mortality rate, abortion rate, and final pregnancy, the variable of treatment effect alone was included. Variables without consistently effect $(\mathrm{P}>0.05)$ were removed from the model. The prevalence rate and frequency analysis for seropositivity were calculated using
Chi-square test for BHV-1, BVDV, and BL to verify differences among the experimental groups.

\section{RESULTS AND DISCUSSION}

Serological results for BHV-1, BVDV, and $\mathrm{BL}$ are shown in table 1; we observed no significant differences of these values among the experimental groups. Previous studies in the Pantanal region have reported prevalence rates based on serological evidence of the presence of infectious agents under endemic conditions in the experimental groups (PELLEGRIN et al., 1997; PELLEGRIN et al., 1999, JULIANO et al., 2011). However, the epidemiology of the diseases in this region, especially IBR and $\mathrm{BVD}$, remain unclear.

In our study, we obtained Leptospira spp. agglutination of $100 \%$ in the samples before vaccination, which is higher than the mean values reported by FAVERO et al. (2001) of 45.6 to $62.3 \%$ for different Brazilian states, and the value of $66.0 \%$ reported by MIASHIRO et al. (2018) in a prevalence study conducted in the Pantanal area of Mato Grosso do Sul; however, our result is similar to the value of $81.1 \%$ reported by FIGUEIREDO et al. (2009), in a study to investigate leptospirosis in cows at similar reproductive age to that of our study population. These differences can be explained by the fact that epidemiology of leptospirosis is influenced by environmental factors in the region or even intrinsic factors of the farm.

GAY (2009) reported that a population with seropositivity of 70 to $80 \%$ would be resistant to the spread of most infectious agents due to high immunity and lower susceptibility of the animals. This phenomenon results from the complex dynamics of factors involving host susceptibility

Table 1 - Prevalence rates of seropositivity for bovine herpesvirus-1 (BHV-1), bovine viral diarrhea virus (BVDV), and bovine leptospirosis (BL) in groups of Nellore heifers by treatment (T1-T4).

\begin{tabular}{lccc}
\hline & & & \\
& & & \\
& & & \\
Treatment & BHV-1 & BL & \\
T1 & $77.0(\mathrm{n}=26)$ & $88.0(\mathrm{n}=26)$ & $100.0(\mathrm{n}=26)$ \\
T2 & $79.0(\mathrm{n}=24)$ & $67.0(\mathrm{n}=24)$ & $100.0(\mathrm{n}=25)$ \\
T3 & $83.0(\mathrm{n}=24)$ & $87.0(\mathrm{n}=24)$ & $100.0(\mathrm{n}=26)$ \\
T4 & $94.0(\mathrm{n}=16)$ & $87.0(\mathrm{n}=16)$ & $100.0(\mathrm{n}=23)$ \\
Chi-square $^{*}$ & $\mathrm{P}=0.55$ & $\mathrm{P}=0.14$ & - \\
\hline
\end{tabular}

T1, control without vaccination; T2, vaccination against BL; T3,vaccination against BHV-1 and BVDV; T4, vaccination against combination of BL + BHV-1 and BVDV vaccination. * Significant difference at P-value of $<0.05$.

Ciência Rural, v.49, n.11, 2019. 
and immunity, animal density, and environmental infection-pressure. Based on this knowledge, and the high prevalence rates of the experimental groups in our study, the seroepidemiological information of the herds has potential for use to support strategic health management decisions when combined with zootechnical information on reproductive performance.

We detected Leptospira spp. Serovars with high agglutination frequency in the sample $(\mathrm{n}=100)$, in order, of Hardjo $(95.0 \%)$, Tarassovi $(91.0 \%)$, Wolffi $(87.0 \%)$, Bratislava $(82.0 \%)$, Icterohaemorragiae $(64.0 \%)$, Hebdomadis $(63.0 \%)$, and Pomona (29.0\%); among these, the highest agglutination frequency, with titers above 1:800 were Hardjo (53.7\%), Tarassovi (28.6\%), Wolffi (27.6\%), Bratislava (23.17\%), and Pomona (6.9\%).

In Brazil, serological investigations of bovine populations have reported Hardjo, Wolffi, Pomona, Grippotyphosa, Icterohaemorrhagiae, and Canicolaasthe most prevalent serovars, and of these, Hardjoranks highest (FAVERO et al., 2001).

The variety of serovars involved in heifer infection were similar to those reported in other studies conducted in the Pantanal region, where domestic-wild animal interface is a determining factor in the ecology of bovine leptospirosis (PELLEGRIN et al., 1999; JULIANO et al., 2011, MIASHIRO, 2013; VIEIRA et al., 2016), and represent the largest reservoir populations of this farm, which maintain the agents in the environment.

BHARTI et al. (2003) reported serovar reservoirs of Hardjo and Wolffi in cows, Tarassovi in pigs, Bratislava in pigs and horses, Icterohaemorragiae in rodents, Hebdomadis in deer, and Pomona in cows and pigs.
In the comparison among groups, there was no difference in the mean body weight before the breeding season $(\mathrm{P}>0.05)$. Embryonic death rate was in the range of 1.5 to $2.8 \%$; whereas, pregnancy rate at the end of the reproductive season was in the range of 87.7 to $90.5 \%$. Although, we observed fetal losses of 5.6 to $7.4 \%$ in the experimental herd, the birth rates remained between 81.9 and $83.1 \%$, which are considered as satisfactory reproductive indices for the production system as compared to those of previous reports (OLIVEIRA et al., 2015; NOGUEIRA et al., 2016). Moreover, there were no differences $(P>0.05)$ in the pregnancy, embryonic mortality, and fetal mortality rates among groups undergoing different vaccine protocols (Table 2 ).

In our study, there was no significant difference in the occurrence of abortions among the groups. A meta-analysis of 15 studies on BHV1 by NEWCOMER et al. (2017b) reported a lower risk of abortion in vaccinated animals, both under experimental challenge (mean reduction of $60 \%$ ) and field conditions (mean reduction of $35 \%$ ). However, this result may vary with type of vaccine, viral strain in the vaccine and field, intensity of challenge, and animal immunity. A meta-analysis of 27 studies on the impact of BVDV vaccination indicated an approximate reduction in the risk of abortion of $45 \%$; the authors recommended that vaccination of naturally infected heifers should be conducted with caution considering the economic impact (NEWCOMER et al., 2017a). Based on these results and those of our study, vaccination alone is not effective to control these diseases and associated reproductive losses.

The endemic infection in our study herd maintained conditions of active immunity, thereby

Table 2 - Body weight at the beginning of FTAI $(\mathrm{kg})$, FTAI pregnancy rate $(\%)$, pregnancy rate at the end of the breeding season (D120,\%), embryonic mortality (\%), and fetal mortality (\%) by treatment (T1-T4)

\begin{tabular}{|c|c|c|c|c|c|c|c|}
\hline \multirow[t]{2}{*}{ Treatment } & \multirow{2}{*}{$\begin{array}{l}\text { Number of } \\
\text { animals }\end{array}$} & \multirow{2}{*}{$\begin{array}{l}\text { Initial weight } \\
\qquad(\mathrm{kg})\end{array}$} & \multirow{2}{*}{$\begin{array}{c}\text { Pregnancy } \\
\text { rate }(\%) \\
\text { D30 }\end{array}$} & \multirow{2}{*}{$\begin{array}{c}\text { Embryonic } \\
\text { mortality (\%) } \\
\text { D60 }\end{array}$} & \multirow{2}{*}{$\begin{array}{l}\text { Pregnancy rate }(\%) \\
\text { D120 }\end{array}$} & \multirow{2}{*}{$\begin{array}{c}\text { Fetal } \\
\text { mortality } \\
(\%)\end{array}$} & \multirow{2}{*}{$\begin{array}{c}\text { Birth } \\
\text { rate }(\%)\end{array}$} \\
\hline & & & & & & & \\
\hline $\mathrm{T} 1$ & 190 & $344.68 \pm 28.84$ & 42.2 & 2.1 & 90.5 & 7.4 & 83.1 \\
\hline $\mathrm{T} 2$ & 195 & $340.84 \pm 31.85$ & 46.1 & 2.0 & 87.7 & 5.6 & 82.1 \\
\hline $\mathrm{T} 3$ & 194 & $340.13 \pm 29.12$ & 34.4 & 1.5 & 88.1 & 6.2 & 81.9 \\
\hline $\mathrm{T} 4$ & 184 & $343.51 \pm 27.03$ & 45.1 & 2.8 & 88.9 & 6.1 & 82.8 \\
\hline $\mathrm{p}$ & - & 0.87 & 0.14 & 0.88 & 0.91 & 0.91 & - \\
\hline
\end{tabular}

EM, embryonic mortality. T1, control without vaccination; T2, vaccination against BL; T3, vaccination against BHV-1 and BVDV; T4, vaccination against combination of BL + BHV-1 and BVDV. " Significant difference at P-value of $<0.05$. 
limiting onset of acute clinical signs that lead to poor reproductive performance, which corroborates the previous report that specific antibodies through previous pathogen exposure are inadequate indicators of the infection state (BARRETT et al. 2018).

Low titers of 1:100 and 1:200 indicated endemic leptospirosis; nevertheless, we considered that individual titers of above 1:800 characterized active infection with possible leptospiruria, and elimination of important serovars such as Hardjo $(53.7 \%)$ and Pomona $(6.9 \%)$ often involved in reproductive disorders. This finding may explain the occurrence of embryonic and fetal mortality in the study herd (Table 2), since chronic infection with these serovars causes fetal losses at different stages of pregnancy in isolated events, which is not a characteristic clinical feature of acute infections (ADUGNA, 2016).

This hypothesis is corroborated by JUNQUEIRA et al. (2006), who reported fewer reproductive problems in herds with endemic infections that occur only in the members without immunity. The authors emphasized that susceptible individuals are expected to show acute signs of clinical infection, and since IBR, BVD, and BL agents cause similar reproductive disorders, the laboratory results of serology should be interpreted carefully. The confirmed diagnosis should be based on results through direct diagnostic techniques, identification of the agent in clinical abortion material, and paired serology to identify seroconversion.

Our result of absence of interference of the vaccination protocols with the reproductive performance of heifers corroborates the findings of FERREIRA et al. (2018) on reproductive performance of pluriparous animals in a similar region and under similar production system to those in the present study. Similar experimental and geographic conditions explain the fact that similar results were obtained under field setting with multifactorial interference.

AONO et al. (2013) included several farms with extensive production system in their study, and reported a positive effect of vaccination on the pregnancy rate and gestational losses in primiparous and pluriparous cows. However, while those authors reported that farm effect was a significant influencing factor of reproductive performance and there were differences of reproductive performance by animal class, they did not evaluate the effect of seropositivity or other variables unrelated to prophylactic management. These facts may explain the differences in results obtained between studies.
Thus, it is expected that production system (management, animal density, and ecosystem conditions) and herd (animal class, physiological condition or immunity) particular characteristics could influence the results obtained in such studies.

Considering the hypothesis that pregnancy failure in heifers could be associated with other variables independent of herd infection related to these diseases or the prophylactic management tested, we verified if the inseminator, bull, body condition, and reproductive maturity of breeding cows were influencing factors of the reproductive indices in the experimental groups.

The variables of BCS $(p=0.2330)$, bull $(p=0.1796)$, inseminator $(p=0.2258)$, and maturity of the reproductive tract $(p=0.7258)$ were not significant factors of FTAI pregnancy, and were removed from the model, which is in contrast to findings of previous reports of the relationship of BCS with higher pregnancy rates in beef cattle (JAUME, 2002; FERREIRA et al., 2013).

However, BW ( $\mathrm{p}=0.008)$ (Figure 2) and the presence of estrus near the FTAI date had positive association with the pregnancy rate $(\mathrm{P}<0.001)$, but no interaction with the treatments, which corroborates the results of NOGUEIRA et al. (2016).

Thus, the non-interference of vaccination in the reproductive performance of heifers in our study may be related to immunity of the herd to IBR, BVD, leptospirosis. BALAKRISHNAN \& REKHA (2018) reported that active natural or vaccine-mediated immunity in $80 \%$ of a population would result in a lower proportion of susceptible individuals, as well as lower spread rates of the infectious agent; and consequently, lower infection pressure on the herd, which would reduce clinical manifestations of some diseases.

The natural immunity of heifers in our study may have conferred similar levels of reproductive performance independent of the effects of vaccination, in agreement with LOPES et al. (2010a, 2010b), who concluded that natural immunity against bovine leptospirosis and BVDV has a protective effect with regard to performance and reproductive losses in beef and dairy herds, respectively.

Thus, seroepidemiological aspects of these diseases, influencing factors of the immunological conditions of the animals, history of reproductive performance, herd management, and cost-benefit issues should be investigated more closely and considered in the planning of optimum prophylactic management of the herd. 


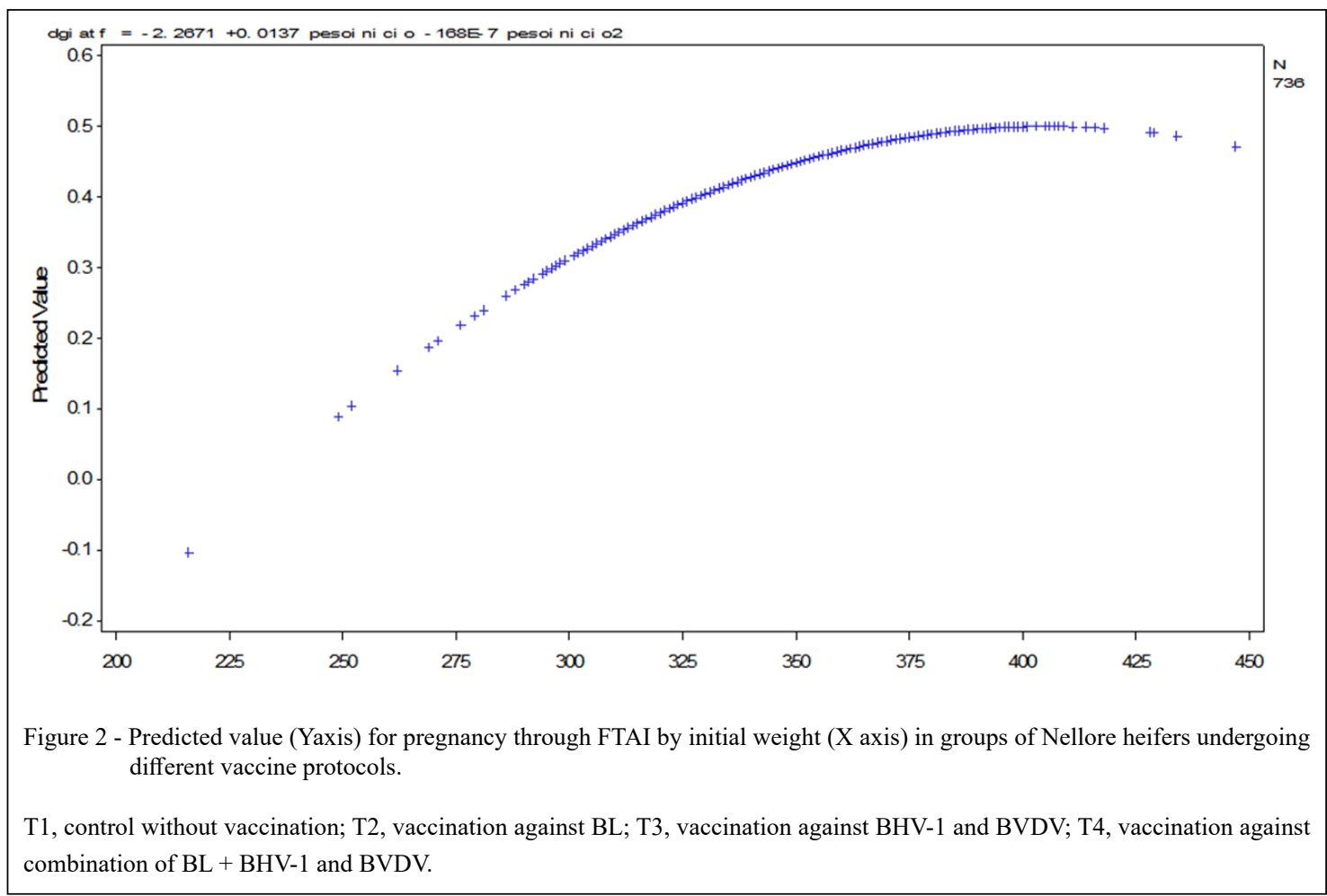

\section{CONCLUSION}

Under the study conditions, whether or not to use different vaccination protocols, against BVHV$1, \mathrm{BVDV}$ and BL, resulted in similar reproductive performances when applied to herds of Nellore heifers raised under extensive system in the Pantanal region who underwent FTAI.

\section{ACKNOWLEDGEMENTS}

The authors thank Empresa de Pesquisa Agropecuária (Embrapa) for funding in the Project 32.13.14.011.00.00.and was financed in part by the Coordenação de Aperfeiçoamento de Pessoal de Nível Superior (CAPES), Brasil - Finance code 001. Thanks to the "Fazenda Bodoquena" team for their support in the fieldwork; Iagro and UFG for collaboration in laboratory analysis.

\section{BIOETHICS AND BIOSSECURITY COMMITTEE APPROVAL}

All activities developed in this experiment were approved by the Animal Use Ethics Committee (CEUA) of Embrapa Gado de Corte, identified by protocol 002/2015.

\section{DECLARATION OF CONFLICT OF INTERESTS}

The authors declare no conflict of interest. The founding sponsors had no role in the design of the study; in the collection, analyses, or interpretation of data; in the writing of the manuscript, and in the decision to publish the results.

\section{AUTHORS' CONTRIBUTIONS}

All authors contributed equally for the conception and writing of the manuscript. All authors critically revised the manuscript and approved of the final version.

\section{REFERENCES}

ABREU U.G.P., et al.. Introdução de tecnologias no sistema de produção de bovino de corte no Pantanal - sub-região de Nhecolândia, MS. Corumbá: EMBRAPA-CPAP, 2000. 37p. (EMBRAPA-CPAP. Circular Técnica, 25). Available from: $<$ https:/www.infoteca.cnptia.embrapa.br/infoteca/bitstream/ doc/806084/1/CT25.pdf>. Accessed: Nov. 01, 2018.

ABREU U.G.P., et al. Sistema Intensivo de Produção na Região Tropical Brasileira -o caso do Pantanal. EMBRAPACPAP, 202018. 26p. (EMBRAPA-CPAP. Documentos, 155). Available from: < https://ainfo.cnptia.embrapa.br/digital/bitstream/ item/174991/1/DOC-155-Urbano.pdf>. Accessed: Nov. 01, 2018.

ADUGNA, S.Areview of bovine leptospirosis. Eur.J.Appl.Sci.,v.8, n.6,p.347-355,2016. Available from: $<$ https://pdfs.semanticscholar. org/ 5 fc8/ad34b9bf9fb 1e 113240c9cabd2cee68a272e.pdf $>$. Accessed: Feb, 11, 2019. doi: 10.5829/idosi.ejas.2016.347.355.

ALVARES, C.A. et al. Köppen's climate classification map for Brazil. Meteorologische Zeitschrift, v.22, n.6, p.711-728, 2013.

Ciência Rural, v.49, n.11, 2019. 
Available from: <https://doi.org/10.1127/0941-2948/2013/0507>. Accessed: Nov. 01, 2018. doi: 10.1127/0941-2948/2013/0507.

AONO F.H. et al .Effects of vaccination against reproductive diseases on reproductive performance of beef cows submitted to fixed-timed AI in Brazilian cow-calf operations. Theriogenology. v.79, n.2, p.242-248, 2013. Available from: <https://doi. org/10.1016/j.theriogenology.2012.08.008>. Accessed: Nov. 01, 2018. doi: 10.1016/2012.08.008.

BALAKRISHNAN S.; REKHA V.B. Herd immunity: An epidemiological conceptto eradicate infectious diseases. J. Entomol Zool Stud, v.6, n.2, p.2731-2738, 2018. Available from: $<$ http://krishikosh.egranth.ac.in/bitstream/1/5810060141/1/ TNV_JEZS_2018_6\%282\%29_2731-2738.pdf>. Accessed: Feb. 10, 2018

BARRETT D. et al. Prevalence of bovine viral diarrhea virus (BVDV), bovine herpes virus 1 (BHV 1), leptospirosis and neosporosis, and associated risk factors in 161 Irish beef herds. BMC Vet. Res. v.14, n.1, p.1-8, 2018. Available from: $<$ https://doi. org/10.1186/s12917-017-1324-9>. Accessed: Nov. 01, 2018. doi: 10.1186/s12917-017-1324-9.

BHARTI, A.R. et al. Leptospirosis: a zoonotic disease of global importance. The Lancet Infectious Diseases. v.3, n.12, p.757771, 2003. Available from: <https://doi.org/10.1016/S14733099(03)00830-2>. Accessed: Nov. 01, 2018. doi: 10.1016/S14733099(03)00830-2.

COLÉGIO BRASILEIRO DE REPRODUÇÃO ANIMAL -CBRA Manual para exame andrológico e avaliação de sêmen animal. 3. ed. Belo Horizonte: CBRA, 2013. 104p.

FAVERO, M. et al. Bovine leptospirosis. most frequent serovars in blood collections performed between 1984 to 1997 from herds of 21 Brazilian State. Arquivos do Instituto Biológico. v.68, n.2, p.29-35, 2001.

FERREIRA, M.C.N. et al. Impacto da condição corporal sobre a taxa de prenhez de vacas da raça nelore sob regime de pasto em programa de inseminação artificial em tempo fixo (IATF). Semina: Ciências Agrarias, v.34, p.1861-1868, 2013. Available from: $<$ http://www.redalyc.org/pdf/4457/445744122032.pdf $>$. Accessed: Nov. 01, 2018. doi: 10.5433/1679-0359.2013v34n4p1861.

FERREIRA, L.C. et al. Impact of vaccination on the reproductive performance of multiparous Nellore cows. Pesquisa Veterinária Brasileira, v.38, n.3, p.456-461, 2018. Available from: <http:// dx.doi.org/10.1590/1678-5150-pvb-5249>. Accessed: Nov. 01, 2018. doi: 10.1590/1678-5150-pvb-5249.

FIGUEIREDO, A.O. et al. Prevalência e fatores de risco para a leptospirose em bovinos de Mato Grosso do Sul. Pesquisa Veterinária Brasileira. v.29, n.5, p.375-381, 2009. Available from : <http://dx.doi.org/10.1590/S0100-736X2009000500003> Accessed: Nov. 01, 2018. doi: 10.1590/S0100-736X2009000500003.

GAY, J.M. Epidemiology concepts for disease in animal groups. 2009. Available from: $<$ https://courses.internal.vetmed. wsu.edu/jmgay/epidemiology-concepts-for-disease-in-animalgroups\#The $\% 20$ herd $\% 20$ immunity $\% 20$ concept $>$. Accessed: May, 14, 2018

GUTIERREZ, K. et al. Effect of reproductive tract scoring on reproductive efficiency in beef heifers bred by timed insemination and natural service versus only natural service. Theriogenology. v.81, p.918-924, 2014. Available from: $<$ https://doi.org/10.1016/j. theriogenology.2014.01.008>. Accessed: Nov. 01, 2018. doi: 10.1016/j.theriogenology.2014.01.008.

IBGE. Pesquisa Pecuária Municipal. v.43, 2015.Available from: <http://biblioteca.ibge.gov.br/visualizacao/periodicos/84/ ppm_2015_v43_br.pdf $>$. Accessed: May, 02, 2017. doi: 10.1016/j.theriogenology.2014.01.008.

JAUME, C.M.; MORAES, J.C.F. Importância da condição corporal na eficiência reprodutiva do rebanho de cria. EMBRAPA - Pecuária Sul, n.43, p.1-30. (Documentos), 2002. Available from: $<$ https://www.infoteca.cnptia.embrapa.br/infoteca/ bitstream/doc/227716/1/DC43.pdf>. Accessed: Nov. 01, 2018.

JULIANO, R. et al. Aspectos sanitários dos Núcleos de conservação in situ de Bovinos Pantaneiros. Boletim de Pesquisa n.103, Embrapa Pantanal, 2011. p.16. Available from: $<$ https://www.infoteca.cnptia.embrapa.br/infoteca/bitstream/ doc/897555/1/BP103.pdf>. Accessed: Nov. 01, 2018.

JUNQUEIRA, J.R.C. et al. Avaliação do desempenho reprodutivo de um rebanho bovino de corte naturalmente infectado com o BoHV-1, BVDV e Leptospira hardjo. Semina: Ciências Agrárias. v.27, n.3, p.471-479, 2006. Available from: <https://www.redalyc. org/pdf/4457/445744081016.pdf>. Accessed: Sep. 20, 2018.

LOPES, L.B. et al. Effect of Leptospira sp. infection on reproductive efficiency of a crossbreed cattle herd in the south of Bahia State, Brazil. Rev. Bras. Med. Vet. v.32. n.1, p.5154, 2010a. Available from: <https://www.researchgate.net/ profile/Luciano_Lopes/publication/236132191_EFFECT_ OF_Leptospira_sp_INFECTION_ON_REPRODUCTIVE_EFFICIENCY OF A CROSSBREED CATTLE HERD IN_THE_SOUT $\bar{H} \_-\mathrm{OF}_{-}$B AHIA_S TATE_B $\overline{\mathrm{R} A Z I L} /$ links/02e7e-51640a152234ā000000/EFFECT-OF-Leptospirasp-INFECTION-ON-REPRODUCTIVE-EFFICIENCY-OF-ACROSSBREED-CATTLE-HERD-IN-THE-SOUTH-OF-BAHIASTATE-BRAZIL.pdf>. Accessed: Jul. 06, 2019.

LOPES, L.B. et al. Efeito do perfil sorológico para diarréia (BVD) viral bovina em índices reprodutivos de rebanhos leiteiros. Rev. Bras. Med. Vet. v.32, n.3, p.133-138,2010b. Available from: <https://www.researchgate.net/publication/234092527_ EFEITO DO PERFIL SOROLOGICO PARA DIARREIA BVDVIRAL_BOVINA__EM_INDICES_REPRODUTIVOS_DEREBANHŌS_LEITEIROS $>\overline{>}$. Accessed: Jul. 06, 2019.

MAAS, J. Relationship between nutrition and reproduction in beef cattle. Veterinary Clinics of North America: Food Animal Practice. v.3, n.3, p.633-646, 1987. Available from: <https://doi. org/10.1016/S0749-0720(15)31135-X>. Accessed: Nov. 01, 2018. doi: $10.1016 / \mathrm{S} 0749-0720(15) 31135-\mathrm{X}$.

MIASHIRO, A.F. et al. Prevalência de leptospirose em rebanhos bovinos no Pantanal de Mato Grosso do Sul. Pesquisa Veterinária Brasileira. v.38, n.1, p.41-47, 2018. Available from: <https://www.alice.cnptia.embrapa.br/alice/bitstream/ doc/1092288/1/16785150pvb380141.pdf>. Accessed: Nov. 01, 2018. doi: 10.1590/S0100-736X2018000100007.

NEWCOMER, B.W. et al. Prevention of abortion in cattle following vaccination against bovine herpesvirus 1: A meta-analysis. Preventive Veterinary Medicine. v.138, p.1-8, 2017a. Available from: <https://doi.org/10.1016/j. 
prevetmed.2017.01.005>. Accessed: Nov. 01, 2018. doi: 10.1016/j.prevetmed.2017.01.005.

NEWCOMER, B.W. et al. Efficacy of bovine viral diarrhea virus vaccination to prevent reproductive disease: A meta-analysis. Theriogenology. v.83, n.3, p.360-365, 2017b. Available from: $<$ https://doi.org/10.1016/j.theriogenology.2014.09.028>. Accessed: Nov. 01, 2018. doi: 10.1016/j.theriogenology.2014.09.028.

NOGUEIRA, E. et al. Taxa de prenhez de vacas Nelore submetidas a protocolos de IATF no Planalto Boliviano. Corumbá: Embrapa Pantanal (Embrapa Pantanal. Circular Técnica, 101), 2011. p.5. Available from: <https://www.infoteca.cnptia embrapa.br/infoteca/bitstream/doc/921333/1/CT101lancado.pdf $>$. Accessed: Nov. 01, 2018.

NOGUEIRA, E. et al. IATF + CIO: estratégia prática de avaliação de cio e aumento de prenhez. Corumbá: Embrapa Pantanal (Embrapa Pantanal. Circular Técnica, 113), 2016. p8. Available from: <http:/www.embrapa.br/pantanal/publicacoes/ online/CT113.pdf>. Accessed: May, 17, 2018.

OLIVEIRA, N.M. et al. Environmental effects on reproductive performance of Nellore cows widely raised in the Cerrado/ Pantanal ecotone. Acta Scientiarum Animal Science. v.37, n.1, p.77-82, 2015. Available from: <http://dx.doi.org/10.4025 actascianimsci.v37i1.24391>. Accessed: Nov. 01, 2018. doi: 10.4025/actascianimsci.v37i1.24391.
PELLEGRIN, A.O. et al. Prevalência da leptospirose em bovinos do Pantanal Mato-Grossense. Comunicado Técnico 22, Embrapa Pantanal, Corumbá, 1999. p.1-9,. Available from: <https://www. infoteca.cnptia.embrapa.br/infoteca/bitstream/doc/805159/1/ COT22.pdf>. Accessed: Nov. 01, 2018.

PELLEGRIN, A.O. et al. Doenças da reprodução em bovinos no Pantanal: ocorrência de animais soropositivos para os vírus da rinotraqueíte infecciosa bovina, diarréia bovina à vírus e língua azul. Corumbá: Embrapa. n.20, (Comunicado Técnico,), 1997. p.7. Available from: <https://ainfo.cnptia embrapa.br/digital/bitstream/item/79391/1/COT20.pdf $>$. Accessed: Nov. 01, 2018.

SANTA ROSA, C.A. Diagnóstico laboratorial da leptospirose. Revista de Microbiologia. v.1, n.2, p.97-109, 1970.

SANTOS, S.A. et al. Sistema de produção de gado de corte do Pantanal. Corumbá, Embrapa Pantanal, n.1, (Sistema de Produção), 2002. p.82. Available from: <https://www.alice. cnptia.embrapa.br/alice/bitstream/doc/809732/1/Livro016.pdf $>$. Accessed: Nov. 01, 2018.

VIEIRA, A.S. et al. Detection of wild animals as carriers of Leptospira by PCR in the Pantanal biome, Brazil. Acta Tropica. v.163, p.87-89, 2016. Available from: <https://doi.org/10.1016/j. actatropica.2016.08.001>. Accessed: Nov. 01, 2018. doi: 10.1016/j. actatropica.2016.08.001. 